\title{
MANUSCRIPT, PRINT AND THE MARKET FOR MUSIC IN EARLY MODERN EUROPE
}

\author{
IAIN FENLON \\ University of Cambridge
}

\begin{abstract}
Izvleček: Prispevek se posveča spreminjajočim se težiščem dveh večjih aspektov širitve glasbenih virov $v$ zgodnjem novem veku - med razširjanjem $v$ rokopisih in tiskih na eni strani ter med geografskimi »središči« in »obrobji«na drugi. Procesi so prikazani na primeru širitve moteta Aspice Domine Jacqueta iz Mantove. V središč dinamike obeh procesov sledimo razvoju rastočega trga za tiskane glasbene knjige, ki so ga stimulirali tako tehnološki izumi kot pomembne spremembe odnosa družbe do same glasbene umetnosti, spremembe, ki so se same promovirale skozi medij tiska.
\end{abstract}

Ključne besede: geografija knjige, zgodnji novi vek, glasbeni rokopisi, glasbeni tiski, Aspice Domine Jacqueta iz Mantove.

\begin{abstract}
The shifting tensions between two major features of the dissemination of music in the early modern era - between manuscript and printed transmission on the one hand, and between "centre" and "periphery" on the other - are explored in this paper via the example of the dissemination of the motet Aspice Domine by Jacquet of Mantua. Central to the dynamics of both is the evolution of an expanding market for printed books of music, a process stimulated by technological innovation as well as by significant changes in societal attitudes towards the art of music itself-changes that were themselves promoted through the medium of print.
\end{abstract}

Keywords: geography of the book, early modern era, music manuscripts, music prints, itineraries, Jacquet of Mantua's Aspice Domine.

In their seminal account of the initial impact of printing Lucien Febvre and Henri-Jean Martin devote an entire chapter to what they describe as "the geography of the book." Their discussion begins once the technology had been invented, when Gutenberg's first apprentices and the workmen who learned from them had already inaugurated the long process by which the printing press and its first operatives gradually moved across the whole of Europe and then beyond, to Asia and South America. This chapter in their book is strategically placed after consideration of the introduction of paper to Europe, the development of the necessary techniques and the network of crafts which linked those involved in the process of authorship and printing. Having established these parameters, the authors lay out the dynamics of the geography of the book through examination of the involvement of influential figures and institutions and the crucial role of economic investment in creating a stable environment in which printing and publishing could flourish. 
Beginning with the enormous demand for printed liturgical books for use in cathedrals and collegiate churches, and later encompassing devotional texts of all kinds for private buyers, the needs of the church were a significant factor in the growth of the market. From an early date presses were also set up in places where lawyers gathered, while in university towns books were needed for teachers and scholars. In order to make a profit, printers also began from an early date to cater for a popular market with cheap books of all kinds produced in smaller formats. ${ }^{1}$

Liturgical books with notation, theoretical texts and, later still, books of music fit well into the pattern which Febvre and Martin describe, forming three quite distinctive sectors of the trade. Between 1476 and 1500 liturgical books with music were produced by some sixty-six printers working in twenty-five European towns and cities. ${ }^{2}$ Mensural music is also found in a small number of fifteenth-century printed books; the earliest, Francesco Niger's Grammatica (Venice: Theodor of Würzburg, 1480), contains sections on metre, rhythm and harmony, the last of which is equipped with notation consisting of four lines of notes with a clef but without staves, printed by type. A decade or so later Michel de Toulouse, working in Paris, printed two pages of mensural notation using rather badly-cast type in his edition of the anonymous L'art et instruction de bien danser (n.d., ca.1496), and in 1499 Johann Emerich of Speyer included a mensural Credo, also printed by type, in his Graduale. Yet another incunabulum, the Historia Baetica (Rome: Eucharius Silber, 1493), written by the Papal Secretary Carolo Verardi, actually includes an anonymous polyphonic Italian song for four voices printed by poorly-cut woodblocks and arranged on facing pages in traditional choirbook format. The first collection of printed polyphony, Petrucci's Odhecaton A of 1501, was sufficiently successful in commercial terms to encourage the re-issue of the book, and during the next decade Petrucci went on to print more than forty editions of chansons, frottole, Masses, motets, laude and intabulations for lute. ${ }^{3}$

By the middle of the sixteenth century not only music itself, but also treatises, textbooks, instruction manuals and tutors were being produced in their hundreds and sometimes thousands to cater for the growing audience for music in the larger urban centres of Italy, France and, some decades later, the areas served by the presses of Susato and Phalèse in northern Europe. ${ }^{4}$ In terms of the geographical distribution of this phenomenon it is perhaps useful to think of a centre roughly speaking bounded by Paris and Lyons to the west, Nuremberg and Frankfurt to the east, Antwerp to the north and Rome to the South, together with a periphery where the impact of printing was sporadic and much slower. In London local printing made little difference to established traditions of transmission until the late $1580 \mathrm{~s}$, and even then it continued to co-exist with manuscript

1 Febvre and Martin, L'Apparition du livre, chap. 6.

2 The standard bibliography of fifteenth-century books containing music notation is Meyer-Baer, Liturgical Music Incunabula, now superseded for books printed in Italy by Duggan, Italian Music Incunabula.

3 See Boorman, Ottaviano Petrucci.

4 For a general treatment of music printing and publishing in the period, see Fenlon, "Music, Print and Society in Sixteenth-Century Europe," and the secondary literature cited there. 
forms, rather than replacing them, to a much greater degree than anywhere within the central area of production. A small number of music books were printed in some of the larger towns and cities of the Iberian peninsula, but, as in England, Poland and other places distant from the main phenomenon, manuscript traditions continued and a great deal of music was imported. By making copies of music available in such quantity, and throughout such a widespread geographical area, the press made a powerful impact on musical culture in general.

In practice, the "geography of the book" which emerges from the pages of L'Apparition du livre incorporates a wide range of interconnected networks. At a local level it is concerned with the bringing together, in a particular locale, of regular supplies of paper, the necessary print technology and skilled workers to produce the book. Interwoven with these considerations are questions of economic, political, intellectual and cultural history, tied together in a grand historical narrative which relates the success of print shops to more general developments. The case which Febvre and Martin outline demonstrates quite how powerfully geography is involved in the production, distribution and consumption of print, and how that makes a difference to the ways in which books and their histories should be understood. It is not surprising that there are also limitations to their enquiry. For Febvre and Martin, the centre of interest was the spread of a new technology applied to the printed book by the printers, apprentices and journeymen who worked the presses. They have comparatively little to say about aspects of cultural history that have come to occupy book historians in recent decades, such as the relationship of print culture to questions of literacy, the transmission and dissemination of individual texts, patterns of reading and book ownership, the propagandistic uses of print and the relationship of print to orality and popular culture. ${ }^{5}$

Although the profound impact of Gutenberg's invention upon all fields of knowledge, learning and information is generally agreed, the impact was neither as immediate nor as wholesale as is sometimes claimed. In this context, the sense of gradual change which Febvre and Martin outline is to be preferred to the dramatic impact of a print revolution argued by Elizabeth Eisenstein in her complex and controversial account. ${ }^{6}$ Nonetheless, while Febvre and Martin convincingly argue for a more gentle evolutionary process, they also neglect the fact that throughout the sixteenth century, and into those that followed, some categories of text continued to circulate in manuscript rather than print, while others were transmitted in both forms. This phenomenon is particularly familiar to musicologists concerned with the early modern period, when some repertories circulated in manuscript before reaching print, while others circulated almost exclusively in manuscript form.

The tension between print and scribal copies relates not merely to the philological task of constructing stemmata and establishing a text but also to the challenges involved in reconstructing the itineraries of books: the routes along which they travelled and the possibilities of textual connections between them. This also means realizing that oral, scribal and printed forms were all part of the equation, both as elements of the history of communication across space and as evidence of local practice. As such, consideration of

5 Ogborn and Withers, Geographies of the Book, 4-5.

${ }^{6}$ Eisenstein, Printing Press. 
the geographies of books of music, both printed and manuscript, serves to highlight the importance of place and the technologies of production and to show how issues of scale, whether related to local meaning, national frames of reference or questions of trans-national reception, must all be taken into account. The transmission history of one of the most frequently copied and printed works of the entire sixteenth century, Jacquet of Mantua's motet Aspice Domine, illustrates the argument in a particularly striking manner.

This piece is an early work. ${ }^{7}$ On account of its text, which is based on the Lamentations of Jeremiah, it seems likely that it was written as a commentary on the condition of Rome following the sack of the city at the hands of the imperial troops in 1527. As such, it belongs to a particular genre of musical compositions, comparatively new at the time, whose texts provide commentaries on Italian social and political conditions. The words run as follows:

Aspice Domine quia facta est desolata civitas plena divitiis: sedet in tristia domina gentium: non est qui consoletur eam, nisi tu Deus noster.

See, Lord, the city once full of riches is deserted; in sadness she sits, once a queen among the nations: there is none to console her, except you, our God.

The medium of print provided access to Jacquet's motet at a comparatively early date. It was printed for the first time in the Motetti del Fiore secundus liber, a collection of twenty-four motets printed by Jacques Moderne in Lyons, a city whose musical life was significantly sustained by the community of Florentine fuorusciti, refugees from the Medici regime in Florence. ${ }^{8}$ Although Moderne's collection was published in 1532, Aspice Domine entered wide currency in print only with its appearance in a collection of the composer's five-voice motets, the Motecta [...] liber primus, printed in Venice by Girolamo Scotto in 1539. ${ }^{9}$ This formed the basis of three later editions brought out both by Scotto and his main competitor in the Venetian trade, Antonio Gardano, between 1540 and 1553.

Leaving aside these printed sources, Aspice Domine also circulated in a number of early sixteenth-century manuscripts. Among them are two sets of partbooks compiled in the 1530s, the first of which is known in the secondary literature as the Vallicelliana partbooks. ${ }^{10}$ Copied in Florence about $1530-1532$ by the scribe of a number of sources in a central complex of related Florentine manuscripts, they were written for a member of the Pucci family and were bound in Rome. ${ }^{11}$ These features help to explain the mixture of Florentine and Roman repertories which the books contain.

The second is a set of five partbooks now in Treviso, where they seem to have been since the end of the sixteenth century; they too date from about $1530 .{ }^{12}$ The strong presence

7 For a modern edition see Jackson and Nugent, Jacquet of Mantua, 48-54.

8 Pogue, Jacques Moderne, 127-130; Dobbins, Music in Renaissance Lyons, 1-7.

9 Bernstein, Music Printing in Renaissance Venice, 232-235.

${ }^{10}$ Rome, Biblioteca Vallicelliana MS S1 35-40 (olim S. Borr. E. II. 55-60). See Lowinsky, "Newly Discovered Sixteenth-Century Manuscript," 173-232, reprinted in Lowinsky, Music in the Culture of the Renaissance, 2:433-482.

${ }^{11}$ For the identification of Moro as the copyist and Roberto di Antonio Pucci as the recipient, see Fenlon and Haar, Italian Madrigal, 128-129.

${ }^{12}$ Treviso, Biblioteca Capitolare, MS 36; see Census Catalogue, 251. 
of music by composers connected to Ferrara suggests that the manuscripts were copied in a Ferrarese ambience if not in the city itself.

To this picture can be added two partbooks from an original set of five now in the private library of the Massimo family in Rome, where they have always been. These books are not so well known and were not taken into account by the editors of Jacquet's complete works. But they contain six motets by the composer, including Aspice Domine. The name "Antonius Maximus" (Antonio Massimo), a sixteenth-century member of the family, is stamped on the contemporary covers of both books, and the bindings themselves seem very close in style to those of the Vallicelliana partbooks. The scribe has been identified as Johannes Ochon, who worked in Rome, and whose hand can be identified in a number of Vatican manuscripts. ${ }^{13}$ There seems little doubt that the Massimo partbooks are Roman in origin, and that they are characteristic of partbooks containing domestic music for Florentine and Roman aristocratic households, of which a number from the period survive; on account of their contents they must date from about $1532-1534 .{ }^{14}$

From this picture a clear pattern emerges. On the basis of the pattern of manuscript transmission, it would seem that shortly after its composition Aspice Domine was known in Roman and Florentine circles. But then we encounter a curiosity. A fourth set of manuscript sources, slightly later in date, known as the Peterhouse partbooks after the Cambridge college where they are now kept, were compiled not in Central or North Italy, nor even in one of the urban centres lying along one of the major trade routes crossing the Alps, but somewhere in England. This is unusual (it is uncommon to find new Italian repertory of the 1530 s in circulation so far north at so early a date), also in terms of survival; the Peterhouse partbooks are remarkable for having escaped destruction during the mid-century political and religious upheavals brought about by Henry VIII's dispute with Rome.

In January 1550 an Act of Parliament was promulgated in London "for the defacing of images and the bringing in of books of old Service in the Church;" the effect was felt in every community in the land. By the end of the reign of Edward VI in 1553 the altars had been taken down and the Mass abolished, while liturgical books of all kinds had been surrendered to the King's commissioners, along with vestments, chalices and church ornaments. ${ }^{15}$ From both the historical documentation as well as the handful of sources that have survived, it is clear that a great deal of polyphony was lost in this savage bout of iconoclasm. In this context the Peterhouse partbooks are a remarkable survival. One of their most intriguing features is the inclusion of Aspice Domine. Although there are certainly other instances of Catholic liturgical music being transmitted to England during the period of Henry VIII, in most cases the sources in question are high-quality court manuscripts that were copied, decorated and in some cases illuminated abroad for presentation to Henry himself; as such, they have more to do with gift exchange and international diplomacy than with practical musical activity. ${ }^{16}$ Since comparison of the readings offered

${ }^{13}$ Census-Catalogue, 115.

${ }^{14}$ Rome, Palazzo Massimo, Cod. VI. C. 6 23-24; see the brief description in Lippmann, "Musikhandschriften und-Drucke," 254-295.

${ }^{15}$ Duffy, Stripping of the Altars, chap. 14.

${ }^{16}$ Dumitrescu, Early Tudor Court. 
in all these early printed and manuscript sources suggests that the Peterhouse version is not in the direct line of descent from any of them, it would seem that it was taken from a manuscript source which no longer survives.

All this suggests that by the 1530 s, by which time Jacquet was firmly established in the service of Cardinal Ercole Gonzaga in Mantua, a small corpus of five-voice motets, including Aspice Domine, was in circulation not only in northern Italy, in contexts associated with the courts of Mantua and Ferrara as well as in Rome and Florence, but even further afield. As this example reminds us, a common feature of the composition and dissemination of new music in Italy in this period is that it circulated in manuscript, often in sources copied for elite patrons, before it reached print. This was particularly true for pieces written around 1530, a time when the still fledgling Italian music printing and publishing trade, substantially concentrated in Rome and already fragile, was adversely affected by the Sack of 1527 and did not recover for some years. ${ }^{17}$ This may help to explain why Jacquet's motet was printed for the first time in Lyons, since the important trade route which linked Lyons and Florence, based on common commercial interests in banking and textiles, also provided a conduit for music and musicians. This was further stimulated by the presence of members of a number of prominent Florentine banking families in Lyons, which brought wealth to the city and energy to its cultural life. The initial reception history of Aspice Domine reflects these geographical realities. Or, to put it another way, the availability of music (and by extension individual pieces, styles, forms and even manners of performance), should be regarded not as an aesthetic category but as a historical fact based on social, political and economic systems.

It is instructive to return to the beginning of what can be recovered of the early transmission history in print of Aspice Domine. Moderne operated in a highly competitive market, and as a result he had to diversify his output. His books range from luxurious folio volumes, primarily directed at church institutions, to the handy octavo editions largely produced for sale at the book fairs, such as the long series of chanson volumes clearly destined for a largely French domestic and amateur public. Evidently, he also competed in the international book market with considerable success, and copies of his editions travelled to Italy, Spain and Portugal as well as to German-speaking areas. The visibility of his titles in the pan-European book trade may partly be explained by the economic benefits brought about by operating from Lyons, where the growth of the book trade during the first half of the sixteenth century was spectacular. By 1545 there were twenty-nine bookshops and sixty-five printing houses at work in the city. ${ }^{18}$

Yet while financial capital was central to the development of the printing and publishing trade in sixteenth-century Lyons, arguably the single most important factor was its geographical position. Situated at the crossroads of one of the busiest trade routes in Western Europe, the city was conveniently connected with the major conurbations of Germany and the Swiss Confederation to the east and those of the Italian peninsula across the Alps to the south. In addition, proximity to the Loire provided easy access to the Atlantic and to the sea routes that connected Nantes to the ports of the Cantabrian

${ }^{17}$ Fenlon, Music, Print and Culture, 38-46.

${ }^{18}$ Gascon, Grand commerce et vie urbaine, 1:307. 
coast. ${ }^{19}$ From Nantes bales of books from Lyon were transported by sea to Bilbao and then overland..$^{20}$ Bilbao was connected in turn to an internal road system which linked it to Valladolid, Burgos, Medina del Campo (the site of the most important Spanish book fair) and the university town of Salamanca.

In addition, Nantes was an important port on the north-south sea route which connected Bilbao with Bruges in Flanders and Antwerp in Brabant, the two most important commercial entrepôts of northern Europe. It was there that Spanish and Portuguese merchants were involved in a lively trade between northern Europe and Spain, which, in addition to dealing in merchandise produced locally, also transported goods of all kinds, including books from Venice, Lyons and Paris. ${ }^{21}$ The route from the English Channel down to the Atlantic then continued to Cadiz, the most important Spanish port for trade with the colonies in the Americas. ${ }^{22}$ Yet while some books from Lyons reached Medina del Campo via Nantes, others were transported down the Rhône to the Mediterranean and then on to Barcelona and Valencia, the two most important ports on the eastern seaboard.

How did these economic realities affect Moderne's commercial decisions about how to market the books that he published? Beginning with the Liber decem missarum of 1532, he printed choirbooks throughout his career, and it was these in particular that found favour in the Iberian market. Printed choirbooks were used throughout Catholic Europe, but in Spain they continued to have a particularly prominent functional role in the enactment of the liturgy after the Council of Trent in large part because of the preservation of the Spanish coro in Spanish collegiate churches and cathedrals despite the emphasis placed upon increased accessibility to, and visibility of, the central sacral area in the Council's decrees. ${ }^{23}$

By the middle of the sixteenth century music printing had expanded the European market for polyphony, and printer-publishers in a number of major cities were producing music in some quantity. This expansion of the market was encouraged by the adoption of single-impression printing, which allowed each sheet to be passed through the press only once. Inaugurated by Pierre Attaignant in Paris in 1528, by the end of the 1530s the technology had been taken up by both Antonio Gardano and Girolamo Scotto in Venice. Inevitably, this had a profound effect on both the concept and the reality of music collecting as it was understood and practised by bibliophiles, professional musicians and cultivated amateurs, whether in institutional or private contexts. The accumulation of music texts, usually for the purposes of assembling a repertory of pieces for performance, was hardly new. But now, to a greater extent than ever before, it was possible for cathedrals and churches, monasteries, confraternities, academies, universities, courts, aristocratic households and members of the merchant and professional classes to acquire substantial

${ }^{19}$ Lapeyre, Une famille de marchands, 170-179. See also the discussion of printer-publishers and their factors operating in Medina del Campo, 567-573.

${ }^{20}$ Mano González, Mercadores e impresores de libros, 200-204.

${ }^{21}$ Exports from Antwerp to the Iberian peninsula in 1553 included four clavichords, fifteen harpsichords, eight lutes, sixty-one monochords, seven organs and quantities of books; see Goris, Étude sur les colonies marchandes, 295-306.

${ }^{22}$ Pike, Enterprise and Adventure, 42-47 and 48-83.

${ }^{23}$ Fenlon, "Printed Polyphonic Choirbooks." 
collections of music for the purposes of performance or study. The example par excellence is that of Hernando Colón, son of the legendary Genoese explorer Cristoforo Colombo, the "discoverer" of America, who assembled a library of 15.370 volumes, making this the largest collection of the time. From both the few books that survive in Seville and his meticulous records, it is clear that Colón owned a copy of nearly every French and Italian book of music known to have been published before 1535, including a considerable number that have not survived in even a single copy. Many of these were acquired not only from booksellers and agents all over Europe but were also bought personally in the course of four extended book-hunting trips to Italy and Northern Europe. ${ }^{24}$

The example of Italy, and above all the operations of Gardano and Scotto, established the music book in the commerce of the trade in a way that was without precedent. During the second half of the sixteenth century music printers proliferated throughout Europe, taking their workshop practices, distribution methods and the format and design of their books from the examples of the early practitioners. Symptomatic of the vitality of the trade, and of the wide geographical spread of its operations, is the appearance of catalogues, beginning with that of Georg Willer advertising the Frankfurt book fairs. This method of distribution affected individual buyers only at one remove, since the fairs were populated by printer-publishers and booksellers rather than private buyers. The earliest surviving bookseller's catalogue, issued by Angelo Gardano in 1591, lists 345 items (mostly sacred and secular vocal music), and was presumably a means of advertising stock to individual customers as well as to bookshops both in Italy and elsewhere. ${ }^{25}$ The effectiveness of the system can be deduced from some of the surviving libraries of the time. The earliest editions in Georg Knoff's library in Danzig, a major port of the Hanseatic League with connections to Venice by sea, date from the 1570 s, but most of them were published between 1580 and the early 1600s. Altogether, Knoff bought 267 titles, the lion's share of which comprises books of Italian madrigals printed in Venice by Gardano. ${ }^{26}$

Although Venice remained at the centre of the music printing and publishing industry throughout the sixteenth and well into the seventeenth century, just as it remained dominant in the book trade in general, the music that was published there could sometimes be transmitted in indirect ways. Traditional commercial patterns could profoundly affect musical taste, as is clear from the familiar example of English enthusiasm for the Italian madrigal at the end of the century: a taste substantially created by the astute entrepreneurship of Thomas Morley. ${ }^{27}$ Many of the versions copied into English manuscripts from the 1560s onwards, after the accession of Elizabeth I had secured both greater stability in the country and a more cosmopolitan cultural outlook, were taken from northern printed sources (particularly the anthologies produced by Phalèse in Antwerp) rather than from Venetian editions. ${ }^{28}$ In music, as in contemporary architecture, the English taste for the

\footnotetext{
${ }^{24}$ Chapman, "Printed Collections of Music," 34-84.

${ }^{25}$ Mischiati, Indici, cataloghi e avvisi, 83-92.

${ }^{26}$ Morell, "Georg Knoff," 103-126.

${ }^{27}$ Kerman, Elizabethan Madrigal.

${ }^{28}$ For Phalèse, see Vanhulst, Catalogue des editions.
} 
Italianate was acquired at a distance, already sifted to accommodate the preferences of Antwerp merchants and consequently rather wary of progressive stylistic trends.

The gradual widening of the market in the course of the sixteenth century is reflected in the growth of amateur repertories, both vocal and instrumental, as well as in the expanding market for basic theory books and other manuals, the earliest of which had also been produced in Venice in the 1530s. By the middle years of the sixteenth century many men of substance and even a good many of more modest means owned a sizeable general library; as inventories and booklists show, from this date onwards it was increasingly the norm for members of the professional classes to own books, as did also a large proportion of chemists, barber-surgeons and others in trade lower down the social scale. In view of the rather specialized character of musical literacy it is unlikely that the ownership of music penetrated as far as did that of books of history and law. Nevertheless, it is clear that both the size and nature of the public for music changed dramatically from the middle of the century. In this sense, the subsequent history of the impact of music printing can be considered in relation to developments in Italy and to the imitation of those developments elsewhere, not only in terms of book production and design but often also in respect of much of the repertory that was printed. Nonetheless, to discuss books of music only in terms of these features is to conduct a limited enquiry, to see only one part of the historical jigsaw. Consideration of the entire process of production, dissemination and consumption necessarily involves contextualization and is unavoidably geographical in the quest to establish what we take books to be and to do. 


\section{Sources}

Rome, Biblioteca Vallicelliana MS S1 35-40 (olim S. Borr. E. II. 55-60).

Rome, Palazzo Massimo, Cod. VI. C. 6 23-24.

Treviso, Biblioteca Capitolare, MS 36.

\section{Bibliography}

Bernstein, Jane. Music Printing in Renaissance Venice: The Scotto Press (1539-1572).

New York: Oxford University Press, 1998.

Boorman, Stanley. Ottaviano Petrucci: Catalogue raisonné. New York: Oxford University Press, 2006.

Census Catalogue of Manuscript Sources of Polyphonic Music, 1400-1550. Vol. 3. n.p.: American Institute of Musicology, 1984.

Chapman, Catharine W. "Printed Collections of Music Owned by Ferdinand Columbus." Journal of the American Musicological Society 21 (1968): 34-84.

Dobbins, Frank. Music in Renaissance Lyons. Oxford: Clarendon Press, 1992.

Duffy, Eamon. The Stripping of the Altars: Traditional Religion in England, 1400-1580.

New Haven: Yale University Press, 1992.

Duggan, Mary Kay. Italian Music Incunabula: Printers and Type. Berkeley: University of California Press, 1992.

Dumitrescu, Theodor. The Early Tudor Court and International Musical Relations. Farnham: Ashgate, 2007.

Eisenstein, Elizabeth. The Printing Press as an Agent of Change: Communications and Cultural Transformations. 2 vols. Cambridge: Cambridge University Press, 1979.

Febvre, Lucien, and Martin, Henri-Jean. L’Apparition du livre. Paris: Albin Michel, 1958. Fenlon, Iain, and Haar, James. The Italian Madrigal in the Early Sixteenth Century: Sources and Interpretation. Cambridge: Cambridge University Press, 1988.

Fenlon, Iain. "Music, Print and Society in Sixteenth-Century Europe.” In European Music, 1520-1640, edited by James Haar, 280-303. Woodbridge: Boydell and Brewer, 2006. - "Printed Polyphonic Choirbooks for the Spanish Market." In Specialist Markets in the Early Modern Book World, edited by Richard Kirwan and Sophie Mullins, 199-222. Leiden: Brill, 2015.

. Music, Print and Culture in Early Sixteenth-Century Italy: The Panizzi Lectures, 1994. London: The British Library, 1995.

Gascon, Richard. Grand commerce et vie urbaine aux XVI siècle: Lyon et ses marchands (environs de 1520 - environs de 1580). 2 vols. Paris: S.E.V.P.E.N., 1971.

Goris, Jan Albert. Étude sur les colonies marchandes à Anvers. Leuven: Uystpruyst, 1925. Jackson, Philip T., and George Nugent, eds. Jacquet of Mantua: Opera Omnia. Vol 5. Neuhausen: Hänssler-Verlag, 1986.

Kerman, Joseph. The Elizabethan Madrigal: A Comparative Study. New York: American Musicological Society, 1962. 
Lapeyre, Henri. Une famille de marchands, les Ruiz: contribution à l'étude du commerce entre la France et l'Espagne au temps de Philippe II. Paris: S.E.V.P.E.N., 1955.

Lippmann, Friedrich. "Musikhandschriften und -Drucke in der Bibliothek des Fürstenhauses Massimo, Rom. Katalog, I. Teil: Handschriften.” Analecta musicologica 17 (1976): 254-295.

Lowinsky, Edward E. "A Newly Discovered Sixteenth-Century Manuscript in the Biblioteca Vallicelliana in Rome." Journal of the American Musicological Society 30 (1977): 173-232.

Lowinsky, Edward E. Music in the Culture of the Renaissance and Other Essays. Edited and with an Introduction by Bonnie J. Blackburn. 2 vols. Chicago: Chicago University Press, 1989.

Mano González, Marta de la. Mercadores e impresores de libros en la Salamanca del siglo XVI. Salamanca: Ediciones Universidad, 1998.

Meyer-Baer, Kathi. Liturgical Music Incunabula: A Descriptive Catalogue. London: The Bibliographical Society, 1962.

Mischiati, Oscar. Indici, cataloghi e avvisi degli editori e librai musicali italiani dal 1591 al 1798. Florence: Olschki, 1984.

Morell, Martin. "Georg Knoff: Bibliophile and Devotee of Italian Music in Late SixteenthCentury Danzig.” In Music in the German Renaissance: Sources, Styles, and Contexts, edited by John Kmetz, 103-126. Cambridge: Cambridge University Press, 1994.

Ogborn, Miles, and Charles W. J. Withers, eds. Geographies of the Book. Farnham: Ashgate, 2010.

Pike, Ruth. Enterprise and Adventure: The Genoese in Seville and the Opening of the New World. Ithaca: Cornell University Press, 1966.

Pogue, Samuel F. Jacques Moderne, Lyons Music Printer of the Sixteenth Century. Geneva: Librairie Droz, 1969.

Vanhulst, Henri. Catalogue des éditions de musique publiées à Louvain par Pierre Phalèse et ses fils, 1545-1578. Brussels: Palais des académies, 1990. 


\section{ROKOPISI, TISKI IN GLASBENI TRG V ZGODNJENOVOVEŠKI EVROPI}

\section{Povzetek}

V drugi polovici 15. stoletja se je razmnoževanje pisnih besedil vseh vrst začelo seliti s kopistove mize $v$ tiskarske delavnice in s tem se je njihova dostopnost dramatično povečala. Do sredine 16. stoletja je bilo izdanih na stotine, če ne celo na tisoče, ne le glasbenih knjig, temveč tudi teoretičnih spisov, priročnikov, navodil in učbenikov, s katerimi so tiskarji zalagali hitro rastoče glasbeno občinstvo v večjih evropskih mestnih središčih. Izhajajoč iz temeljnih raziskav o pomenu in širjenju tiskanih knjig od izuma tiska dalje in na podlagi tam izdelanega modela t. i. geografije knjige, kot jo definirata Lucien Febvre in Henri-Jean Martin, avtor v razpravo vključuje nekoliko poseben način širjenja glasbenih del, ki so glede na svojo vlogo, najsi bo liturgična, reprezentativna, razvedrilna ali druga, deloma krožila še vedno tudi v rokopisnih prepisih in tudi v obeh oblikah: rokopisni in tiskani. Razlogi so razvejani in kompleksni in segajo ne le v področje same proizvodnje in distribucije knjig, temveč je pri njih treba upoštevati še vrsto drugih vplivov, kot so gospodarski tokovi, trenutna politika ter seveda intelektualno in kulturno ozadje. Pri ugotavljanju poti, ki so jih opravila glasbena dela, najsi v rokopisni ali množičnejši in širše dostopni tiskani obliki, je treba skupaj obravnavati vse oblike, od ustnega izročila do posebnih prepisov in velikih tiskanih naklad in jih osmisliti tako v širšem evropskem prostoru kot tudi mikro lokalni klimi posameznih središč, kjer se je glasba prepisovala in tiskala. Osrednji del je posvečen analizi kompleksnega, a nazornega primera poti raznih oblik moteta Aspice Domine Jacqueta iz Mantove v tridesetih letih 16. stoletja. Skozi ves čas zgodnjega novega veka so nekateri glasbeni repertoarji, ne glede na to, ali so bili ustvarjeni v večjih središčih ali pa v takih, ki jih imamo za obrobnejša, še vedno pogosteje krožili v rokopisih kot v tiskih. Prispevek se zato posveča spreminjajočim se težiščem teh dveh večjih aspektov širitve glasbenih virov v obravnavanem času, med razširjanjem v rokopisih in tiskih na eni strani ter med »središči« in »obrobji« na drugi. V središču dinamike obeh pa sledimo razvoju rastočega trga za tiskane glasbene knjige, procesu, ki so ga stimulirali tako tehnološki izumi kot pomembne spremembe odnosa družbe do same glasbene umetnosti, spremembe, ki so se same promovirale skozi medij tiska. Glasbene knjige so seveda samo en košček v veliki zgodovinski sestavljanki in da ga razumemo pravilno, je treba upoštevati celoto v vsej njeni zapletenosti in kompleksnosti. 